\title{
Assessment of the Quality and Quantity of Organic Matter in the Rufiji Mangrove Surface Sediments Using Biochemical Composition
}

\author{
Daniel Abel Shilla \\ Department of Aquatic Sciences and Fisheries Technology, University of Dar es Salaam, \\ P. O. Box 35064, Dar es Salaam, Tanzania \\ E-mail: dshilla@udsm.ac.tz \\ Received 20 Feb 2021, Revised 28 May 2021, Accepted 29 May 2021, Published May 2021 \\ DOI: https://dx.doi.org/10.4314/tjs.v47i2.35
}

\begin{abstract}
This study was carried out to investigate spatial changes in the quality and quantity of sedimentary organic matter in the Rufiji mangrove system, Tanzania. Sediment samples were collected from three sampling sites. Total organic matter in mangrove sediments ranged from $7.28 \pm 2.02 \%$ to $10.58 \pm 1.34 \%$. Protein concentrations varied from $1,145.33 \pm 20.33 \mu \mathrm{g} / \mathrm{g}$ to $2,747.50 \pm 25.14 \mu \mathrm{g} / \mathrm{g}$ in the mangrove sediments. Total carbohydrates, lipids and biopolymeric carbon in mangrove sediments ranged between $1,110.50 \pm 16.31 \mu \mathrm{g} / \mathrm{g}$ and $1,914.17 \pm 27.79 \mu \mathrm{g} / \mathrm{g}, 1,436.50 \pm 24.13$ $\mu \mathrm{g} / \mathrm{g}$ and $6,373.50 \pm 25.79 \mu \mathrm{g} / \mathrm{g}$, and $4,496 \mu \mathrm{g} \mathrm{C} / \mathrm{g}$ and $10,231.50 \mu \mathrm{g} \mathrm{C} / \mathrm{g}$, respectively. Tannins and lignins in mangrove sediments varied from $817.67 \pm 12.97 \mu \mathrm{g} / \mathrm{g}$ to $1786.50 \pm 30.74 \mu \mathrm{g} / \mathrm{g}$, while stable carbon isotope $\left(\delta^{13} \mathrm{C}\right)$ in Rufiji mangrove sediments ranged between $-26.64 \pm 0.10 \%$ o and $-25.48 \pm 0.13 \%$. Higher protein:carbohydrate (PRT:CHO) at station 3 indicated the presence of freshly deposited organic matter. The high lipid:carbohydrate (LPD:CHO) ratios observed in the Rufiji mangrove systems pointed towards the high quality of labile organic matter which supports benthic fauna. PCA revealed the association of variables and their distribution on trends across sites of the Rufiji mangrove system.
\end{abstract}

Keywords: Organic matter, biochemical composition, Rufiji, mangroves, sediments.

\section{Introduction}

The overall geochemical processes prevailing in any aquatic system cannot be explained merely by the application of geochemical parameters such as general sedimentary characteristics, phosphorus fractionation or heavy metal distribution studies. Redox status of the sedimentary environments is directly linked with diagenesis, the process of organic matter demineralisation (Bouillon et al. 2003). Both autochthonous as well as allochthonous organic compounds resistant to degradation and those that survive diagenesis are stored in sedimentary environments depending on the redox state existing in the aquatic systems.
The assessment of the quantity and quality of organic matter, whether labile or refractory, is a prerequisite for explaining diagenetic processes. The biochemical composition of sedimentary organic matter has been used to gather information on the origin and parameters controlling the diagenetic fate of organic matter (Bouillon et al. 2004). It can be used for the evaluation of the quantity and quality of organic matter which can provide a clear insight into the biogeochemical characterization of the sedimentary environments.

Mangrove ecosystems display strong variability of major biogeochemical characteristics due to their dynamic ecotonal 
locations (Dehairs et al. 2000). Several studies have been carried out in Rufiji estuary on the geochemical characteristics of water and surface sediments in a complex Rufiji mangrove ecosystem, but the quality and quantity of organic matter has been underreported (Shilla 2019, Minu et al. 2020, Shilla and Shilla 2020). This paper investigated the quality and quantity of organic matter in surface sediments of the Rufiji mangroves and adjacent estuarine stations in terms of the biochemical composition. The combinations of elemental and carbon isotopic composition can also be used to distinguish sources of organic matter in sediments and in settling particles (Shilla and Routh 2017). Therefore, along with biochemical composition, $\delta^{13} \mathrm{C}$ of the total organic matter was used to characterize the quality and quantity of organic matter in the study area.

\section{Materials and Methods \\ Description of the study area}

The study sites have been described in Shilla (2019). Briefly, the study sites are located in Rufiji estuary $\left(39^{\circ} 07^{\prime} \mathrm{E}, 7^{\circ} 41^{\prime} \mathrm{S}\right)$ to $\left(39^{\circ} 45^{\prime} \mathrm{E}, 8^{\circ} 15^{\prime} \mathrm{S}\right), 100 \mathrm{~km}$ south of Dar es Salaam City, in the Rufiji River delta (Figure 1). This river has a catchment area of 177,400 $\mathrm{km}^{2}$ and is over $640 \mathrm{~km}$ long (UNEP 2001). About $30 \mathrm{~km}$ from the coast, the lower Rufiji River branches out into a series of channels forming an impressive delta, covering approximately $1200 \mathrm{~km}^{2}$ with $530 \mathrm{~km}^{2}$ covered by mangrove forests (Sørensen 1998). The four northern tributaries carry the bulk of the discharges into the Rufiji River. The southern part of the delta, which is sheltered, receives little fresh water, and the water in front of this part of the delta is clear, saline and features seagrass meadows and scattered patch reefs.

Tidal influence in the delta is considerable (REMP 2003). In the upstream part of the Rufiji catchment area, some small towns are located. Mangrove sections of the downstream part have partially been cleared for rice cultivation (Mshale et al. 2017). The mangroves provide the dominant habitat in the estuary, but tidal marshes, seagrass meadows, and mud-flats are also present. Mangrove forests support an extensive food web through their large production of detritus, which is broken down by fungi and bacteria. Several omnivorous crustaceans of commercial importance spend part of their life cycles in mangroves feeding on the detritus, live benthic microalgae, occasional animal materials, and fine inorganic particles (Minu et al. 2018).

The present study was carried out in three locations (Muhoro-station 1, Msomeni-station 2, and Kalale-station 3), representing the south, middle and northern parts of the Rufiji delta (Figure 1). These locations were chosen because they are representative of the entire estuary and include a variety of adjacent habitats (i.e. mangrove stands, mud flats, and seagrass meadows) with sufficient diversity and densities of consumer organisms. The northern part (Kalale station) frequently develops flow restrictions due to converging tides entering from two adjacent inlets, whereas stations 1 and 2 experience tidal amplification. This well-known biodiverse mangrove wetland is under the threat of severe ecological degradation due to the ongoing activities including the construction of hydroelectric power station as well as agricultural activities. In this context, the surface sediment samples were collected from three locations (Figure 1).

\section{Sampling and analytical methodology}

Surface sediment samples were collected from three locations during June and July 2014 by using a van Veen grab $\left(0.042 \mathrm{~m}^{2}\right)$. In order to obtain a true representation of samples within the study area, sediment samples were collected in triplicates. Sediment samples were stored in clean glass containers and transported to the laboratory on ice and stored in a deep freezer at $-20{ }^{\circ} \mathrm{C}$ till further processing. A portion of the wet sediment from each depthinterval was used for the texture analysis. Sediment texture was determined by pipette method after removing the inorganic carbonates using $10 \% \mathrm{HCl}$ and organic matter using $15 \% \quad \mathrm{H}_{2} \mathrm{O}_{2}$ (Martin et al. 2011). The 
samples were freeze dried and were finely powdered using agate mortar and pestle for further analyses. Organic carbon in sediment samples was analysed using a $\mathrm{C}: \mathrm{N}$ analyser (Carlo Erba Strumentazione NA 1500 nitrogen analyser, UK). To measure the organic carbon, sediment samples (about $10 \mathrm{mg}$ ) were spiked with a few drops of $5 \mathrm{M} \mathrm{HCl}$ and placed in an oven at $50{ }^{\circ} \mathrm{C}$ for at least $1 \mathrm{~h}$ to dry.
Decalcified samples were then analysed in the $\mathrm{C}: \mathrm{N}$ analyser and the values recorded. The quality of this analysis was controlled by analyzing blanks (empty silver capsules) and a standard reference material (acetanilide). Sediment samples were analysed for grain sizes using a grain size analyser (Malvern Instruments Ltd, UK) and various size fractions were composed as recorded.

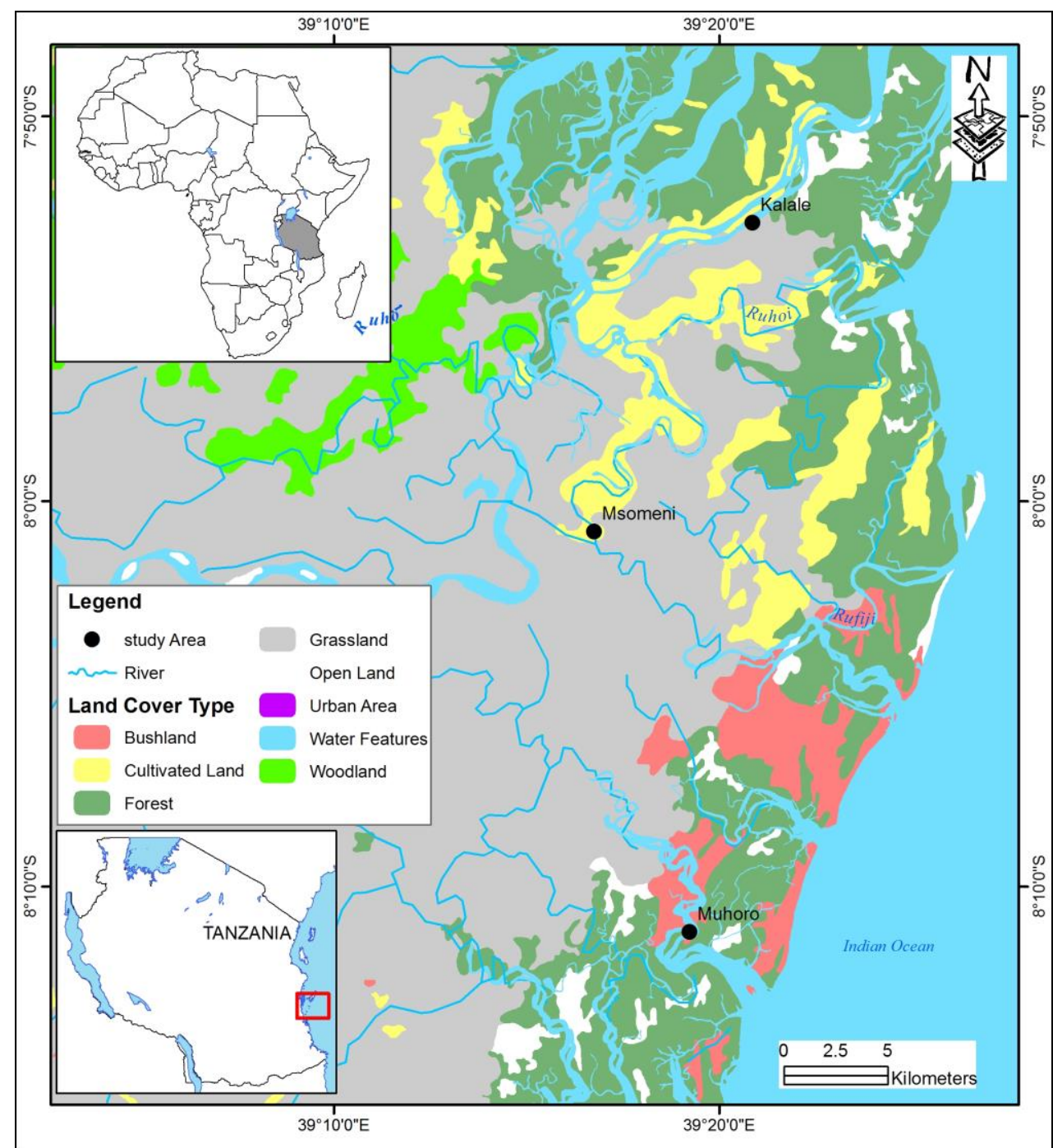

Figure 1: Map showing the study site at Rufiji Estuary, Tanzania. Three sampling locations are indicated in Muhoro stream (station 1), Msomeni (station 2), and Kalale stream (station 3). 
Chlorophyll and phaeopigments (Phe) estimations were carried out according to standard procedures described by Lorenzen and Jeffrey (1980), Tolosa et al. (2004) and APHA (2005). Pigments were extracted with $90 \%$ acetone $\left(24 \mathrm{hrs}\right.$ in the dark at $\left.4{ }^{\circ} \mathrm{C}\right)$. After centrifugation, the supernatant was used to determine chlorophyll pigments (chl-a, chl-b and chl-c) and was acidified with $0.1 \mathrm{~N} \mathrm{HCl}$ to estimate the concentrations of phaeopigments. Tannins and lignins in the sediments were extracted with $0.05 \mathrm{M} \mathrm{NaOH}$ solution for 90 min and filtered. To $5 \mathrm{ml}$ aliquots of filtrates, 1 $\mathrm{ml}$ of citrate solution was added followed by 1 $\mathrm{ml}$ Folin reagent and $10 \mathrm{ml}$ carbonate tartrate reagent and kept for $30 \mathrm{~min}$ and the absorbance was measured at $760 \mathrm{~nm}$. The effects of $\mathrm{Mg}$ and $\mathrm{Ca}$ hydroxides and/or bicarbonates were suppressed by the addition of trisodium citrate solution (Nair et al. 1989). The biochemical constituents, tannins and lignins, and chlorophyll pigments were analysed spectrophotometrically (Double beam UVvisible spectrophotometer: SPECORD 200 PLUS, Analytikjena).

For the extraction of protein (PRT), $0.1 \mathrm{~g}$ of dried sediment was digested in $1 \mathrm{~N} \mathrm{NaOH}$ by heating in a water bath for $5 \mathrm{~min}$ at $100{ }^{\circ} \mathrm{C}$. The slurry was centrifuged, and an aliquot of clear supernatant, was used for estimation of protein using Folin phenol reagents (Lowry et al. 1951). Bovine serum albumin was employed as calibration standard. Carbohydrate (CHO) was analysed following phenolsulphuric acid method (Dubois et al. 1956) using glucose as calibration standard. Total lipids (LPD) from sediment samples were extracted with chloroform and methanol (1:1 v/v, Bligh and Dyer 1959) and estimated using sulphophosphovanillin method (Barnes and Blackstock 1973) employing cholesterol as standard. Concentrations of proteins, carbohydrates and lipids were converted to carbon equivalents by multiplying with the following conversion factors: $0.49,0.40$ and $0.75 \mathrm{~g}$ of $\mathrm{C} / \mathrm{g}$, respectively (Fabiano and Danovaro 1994). The sum of protein, carbohydrate and lipid carbons is referred to as biopolymeric carbon (BPC) (Fichez 1991, Fabiano et al. 1995), which is the amount of carbon available to benthic consumers.

All the analyses were carried out in triplicate and the average reported. For the analysis of sedimentary chlorophyll pigments, $0.5 \mathrm{~g}$ of freeze-dried sample was centrifuged with $90 \%$ acetone at $3000 \mathrm{rpm}$ to separate the pigment from sediment and analysed spectrophotometrically.

Stable carbon isotope abundances are presented as $\delta^{13} \mathrm{C}$ values and are expressed relative to the PDB (Pee Dee Belemnite) standard:

$$
\delta^{13} C=\left(\frac{R_{\text {sample }}}{R_{\text {standard }}}-1\right) \times 1000
$$

where $\mathrm{R}=$ the ratio of the heavy isotope $\left({ }^{13} \mathrm{C}\right)$ over the light isotope $\left({ }^{12} \mathrm{C}\right)$.

\section{Statistical analyses}

Data were processed using the StatView ${ }^{\circledR}$ 5.0.1 (SAS Institute Inc. 1992-1998, Cary, NC), in order to obtain mean values, standard errors and confidence levels. Pearson's product-moment correlation test was used to check for significant relationships between grain size and organic matter content in the sediments. One way Analysis of Variance (ANOVA) was applied to check for differences across sampling stations. Statistical methods were performed with a $95 \%$ confidence interval and $\mathrm{p}<0.05$ significance level.

\section{Results \\ Biochemical composition in the Rufiji mangrove sediments}

The variations of total organic matter (TOM), total organic carbon (TOC), proteins (PRT), total carbohydrates (TCHO) and total lipids (TLP) in the surface sediments of Rufiji mangroves are presented in Table 1. The results of biopolymeric carbon (BPC), chlorophyll concentrations, $\delta^{13} \mathrm{C}$ as well as the spatial variations of PRT/CHO, TLP/CHO, Chl-a/Phaeo, tannins and lignins are also presented in Table 1. 
Shilla - Assessment of the quality and quantity of organic matter in the Rufiji mangrove surface...

Mean total organic matter (TOM) in mangrove sediments ranged from $7.28 \pm 2.02 \%$ to $10.58 \pm 1.34 \%$. Station 3 exhibited higher mean TOM $(10.58 \pm 1.34 \%)$ followed by station $1(8.09 \pm 2.38 \%)$, while the mean TOM in sediments collected from station 2 was 7.28 $\pm 2.02 \%$. No significant difference in TOM was depicted across sites (Table 1; ANOVA, p $=0.203$ ). Mean protein concentrations in sediments of Rufiji mangroves varied from $1,271.33 \pm 22.85$ in station 1 to $2,747.5 \pm 25.14$ in station 3, with values at station 3 significantly higher $(2,747.5 \pm 25.14$; Table 1 ;
ANOVA, $\mathrm{p}=0.034)$ than the values recorded in stations 1 and $2(1,271.33 \pm 22.85$ and $1,145.33 \pm 20.33$, respectively). The quantity of protein nitrogen estimated by multiplying the protein contents with the factor 0.16 (Shilla 2019) for Rufiji mangrove and estuarine sediments varied from $196.64 \pm 3.66$ in station $1,183.25 \pm 3.25$ in station 2 and $439.6 \pm 4.02$ in station 3, making this station to have significantly higher protein contents than the rest of the stations (Table 1; ANOVA, $\mathrm{p}=$ 0.001).

Table 1: Variations of biochemical components in sediments of the Rufiji mangrove system. Results of ANOVA are shown in the last column. Values are mean $( \pm$ SD). TLP $=$ Total lipids; TCHO = Total carbohydrates; PRT = Proteins; $\mathrm{TOC}=$ Total organic carbon; $\mathrm{TOM}=$ Total organic matter; $\mathrm{BPC}=$ Biopolymeric carbon; PRT $-\mathrm{N}=$ Protein nitrogen fraction.

\begin{tabular}{lllll}
\hline & Site $1(\mathrm{n}=9)$ & Site $2(\mathrm{n}=9)$ & Site $3(\mathrm{n}=9)$ & $\begin{array}{l}\text { ANOVA } \\
\text { p-value }\end{array}$ \\
\hline Sand \% & & & & 0.005 \\
Clay \% & $42.12 \pm 16.40$ & $32.01 \pm 12.00$ & $46.82 \pm 20.24$ & 0.001 \\
Silt \% & $18.30 \pm 8.04$ & $19.52 \pm 10.14$ & $20.48 \pm 10.20$ & 0.001 \\
TLP $(\mu \mathrm{g} / \mathrm{g})$ & $36.72 \pm 16.56$ & $28.90 \pm 11.38$ & $40.74 \pm 18.34$ & 0.001 \\
PRT $(\mu \mathrm{g} / \mathrm{g})$ & $2,464.33 \pm 28.09$ & $1,436.50 \pm 24.13$ & $6,373.5 \pm 25.79$ & 0.034 \\
TCHO $(\mu \mathrm{g} / \mathrm{g})$ & $1,271.33 \pm 22.85$ & $1,145.33 \pm 20.33$ & $2,747.50 \pm 25.14$ & 0.454 \\
BPC $(\mu \mathrm{g} / \mathrm{g})$ & $1,204.00 \pm 24.38$ & $1,914.17 \pm 27.79$ & $1,110.5 \pm 16.31$ & 0.014 \\
TOC $(\%)$ & $4,939.66 \pm 26.15$ & $4,496.00 \pm 24.99$ & $10,231.50 \pm 32.52$ & 0.172 \\
TOM $(\%)$ & $4.70 \pm 1.39$ & $4.23 \pm 1.17$ & $6.15 \pm 0.78$ & 0.203 \\
PRT-N & $8.09 \pm 2.38$ & $7.28 \pm 2.02$ & $10.58 \pm 1.34$ & 0.001 \\
Tannins and lignins $(\mu \mathrm{gg} / \mathrm{g})$ & $1,600.33 \pm 24.46$ & $817.67 \pm 12.97$ & $1,786.5 \pm 30.74$ & 0.042 \\
TOC/N & 0.02 & 0.02 & 0.01 & 0.178 \\
PRT/CHO & 1.17 & 0.67 & 2.22 & 0.001 \\
TLP/CHO & 2.32 & 0.90 & 7.86 & 0.003 \\
$\delta^{13}$ C & $-26.38 \pm 0.09$ & $-25.48 \pm 0.13$ & $-26.64 \pm 0.10$ & 0.241 \\
Chlorophyll-a $(\mu \mathrm{g} / \mathrm{kg})$ & $4.54 \pm 0.48$ & $5.64 \pm 1.06$ & $7.55 \pm 2.02$ & 0.005 \\
Chlorophyll-b $(\mu \mathrm{g} / \mathrm{kg})$ & $1.24 \pm 0.06$ & $2.01 \pm 0.01$ & $3.84 \pm 0.87$ & 0.045 \\
Chlorophyll-c $(\mu \mathrm{g} / \mathrm{kg})$ & $1.48 \pm 0.04$ & $2.82 \pm 0.90$ & $4.42 \pm 0.98$ & 0.010 \\
Phaeophytin $(\mu \mathrm{g} / \mathrm{kg})$ & $6.42 \pm 2.74$ & $8.96 \pm 2.84$ & $13.10 \pm 3.64$ & 0.012 \\
Chl-a/Phaeo & $0.71 \pm 0.13$ & $0.63 \pm 0.05$ & $0.58 \pm 0.02$ & 0.124 \\
\hline
\end{tabular}

Total carbohydrates (TCHO) in Rufiji mangrove sediments were similar across stations (Table 1). At station 1, the recorded CHO value was $1,204.00 \pm 24.38$, while at station 2 and 3, the mean $\mathrm{CHO}$ content was $1,914.17 \pm 27.79$ and $1,110.5 \pm 16.31$, respectively.
Total lipid (TLP) contents in Rufiji mangrove sediments exhibited variations from $1,436.50 \pm 24.13$ at station 2 to $6,373.5 \pm 25.79$ at station 3. The concentration of TLP at station 3 was significantly higher compared to values recorded in both stations 1 and 2 (Table 1; ANOVA, $p=0.001$ ).

The biopolymeric carbon fraction of the 
sedimentary organic carbon in mangrove sediments ranged between 4,496.00 $\pm 24.99 \mu \mathrm{g}$ $\mathrm{C} / \mathrm{g}$ and $10,231.50 \pm 32.52 \mu \mathrm{g} \mathrm{C} / \mathrm{g}$. BPC fraction was significantly higher at station 3 than at other stations, and was least at station 2 (Table 1; ANOVA, p = 0.014). Tannin and lignin contents in mangrove sediments varied from $817.67 \pm 12.97 \mu \mathrm{g} / \mathrm{g}$ to $1,786.50 \pm 30.74$ $\mu \mathrm{g} / \mathrm{g}$ with values higher at station 3 compared to other sites (Table 1; ANOVA, p = 0.042).

Estimated chlorophyll pigments exhibited significant spatial variations and were in the range: chl-a: $4.54 \pm 0.48-7.55 \pm 2.02 \mu \mathrm{g} / \mathrm{kg}$ (ANOVA, p = 0.005), chl-b: $1.24 \pm 0.06-3.84$ $\pm 0.87 \mu \mathrm{g} / \mathrm{kg}$ (ANOVA, $\mathrm{p}=0.012$ ), chl-c: 1.48 $\pm 0.04-4.42 \pm 0.98 \mu \mathrm{g} / \mathrm{kg}$ (ANOVA, $\mathrm{p}=$ 0.010). Concentrations of chlorophyll pigments in the sediments followed the trend: chl-a > chl-c > chl-b (Table 1). Generally, station 3 exhibited significantly higher pigment concentrations compared to stations 1 and 2 (Table 1). The ratio of chl-a to phaeopigments revealed no significant difference across the sites $(\mathrm{p}=0.124)$.

The stable carbon isotope $\left(\delta^{13} \mathrm{C}\right)$ of total organic matter in Rufiji mangrove sediments ranged between $-26.64 \pm 0.10 \%$ and $-25.48 \pm$ $0.13 \%$, with station 3 exhibiting more depleted with ${ }^{13} \mathrm{C}$, whereas station 2 recorded comparative enrichment (Figure 2).

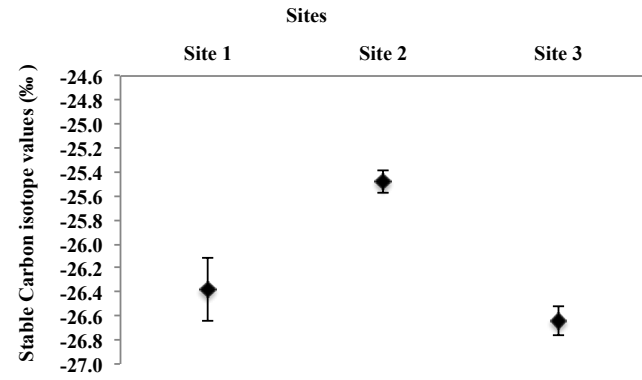

Figure 2: Variation of carbon stable isotopes across three sites in sediments of the Rufiji mangroves system.

\section{Discussion}

The biochemical composition of the Rufiji sedimentary organic matter showed a dominance of lipids followed by proteins and carbohydrates. The biochemical composition of the sedimentary organic matter seems to be quite different from other coastal systems, which is usually characterized by the dominance of proteins and carbohydrates over lipids (Pusceddu et al. 2004). The high concentrations of sedimentary lipids, proteins and carbohydrates recorded in Rufiji mangrove sediments could be related to the morphodynamic, hydrological and physicochemical characteristics of mangrove systems. The shallow water depth and high sedimentation rates of mangrove ecosystems support the settling of organic matter without significant degradation. Significantly higher values of total lipids in the study region especially at station 3 might be due to its preservation under highly anoxic conditions (Manju et al. 2012).

Biopolymeric carbon, which is regarded as the sum of three biochemical compounds (lipids, proteins and carbohydrates) (Manju et al. 2012, Salas et al. 2015), varied from 4,496 to $10,231 \mu \mathrm{g} / \mathrm{g}$ in the mangrove sediments with lipids being the dominant class among labile organic compounds, followed by protein and carbohydrates. LPD contributions to the labile organic matter pool in these sediments at stations 1,2 and 3 were $49.89 \%, 31.95 \%$ and $62.29 \%$, respectively. PRT contributions to the labile organic matter pool at stations 1, 2 and 3 were $25.74 \%, 25.47 \%$ and $26.85 \%$, respectively. $\mathrm{CHO}$ contributions to the total organic matter pool at stations 1, 2 and 3 were $24.37 \%, 42.58 \%$ and $10.85 \%$, respectively. Minu et al. (2020) suggested that about 5-15\% of sedimentary detritus, depending on the environmental characteristics are available at any time for benthic consumers. In this study, BPC exhibited its highest concentration at station 3 in the sediments of Rufiji mangroves accounting for 11 to $62 \%$ of total organic carbon.

The study has revealed that most measured parameters exhibited significant variations across the sites $(p<0.05)$ with higher values at station 3, with exception of CHO, TOC, TOM, TOC/N, Chl-a/Phaeo and $\delta^{13} \mathrm{C},(\mathrm{p}>0.05$, Table 
1). Sedimentary protein concentrations in the Rufiji mangrove system reflected the productivity of marine ecosystems and it appears to be a good descriptor of the trophic status of the benthic systems at different spatial scales (Pusceddu et al. 2004). Carbohydrates which include polyhydroxyllated compounds ranging in size from 5-6 carbon sugars to large biopolymers (starch and cellulose) are much higher in vascular plants than in algae. In mangroves, litter is primarily composed of nonnutritive complex carbohydrates that are difficult or impossible for detritivores to digest. Lipids in sediments are derived not only from aquatic biota, but also from higher plant wax. Lipids in surface sediments are abundant in eutrophic systems than in oligotrophic systems. Like proteins, this also indicates the productivity of the system. The dominance of lipids and protein over carbohydrates indicated the nutritive value as the freshness of the labile organic matter in the sediments of the Rufiji mangrove system.

Protein to carbohydrate ratio (PRT:CHO) is used as an index for determining the origins of materials present in sediments and to distinguish between the presence of fresh materials and the age of sedimentary organic matter (Cividanes et al. 2002). The dominance of carbohydrates and lower PRT:CHO ratio $(<1)$ are typical features of detrital heterotrophic environments (Manju et al. 2012). Since proteins are more readily used by bacteria than carbohydrates, high PRT:CHO ratios indicate recently produced organic matter, while low PRT:CHO ratios suggest the presence of aged organic matter (Manju et al. 2012) and the role of proteins as potentially limiting factor for the benthic consumers (Salas et al. 2015). PRT:CHO ratio varies depending on the depth and the trophic status of the system (Pusceddu et al. 2004). Values of the protein to carbohydrate ratio greater than 1 are typically reported immediately after a microphytobenthic bloom (Salas et al. 2015) or after the deposition of freshly produced phytoplankton (Pusceddu et al. 2004).

PRT:CHO ratio can also be used for classifying benthic trophic status which in turn reflects patterns of nutrient enrichment (Pusceddu et al. 2004). PRT:CHO ratio in the Rufiji mangrove sediments ranged between 0.67 and 2.22. Higher PRT:CHO at stations 1 and $3(>1)$ indicated the presence of fresh organic matter, while a lower ratio (station 2) indicated the presence of aged or less degradable organic matter.

The lipid content and lipid to carbohydrate ratio (LPD:CHO) have been used as good indices for describing the energetic (food) quality of the organic contents in the sediments (Gremare et al. 2002). Lipid concentrations have also been associated with the most labile fraction of sedimentary organics and it is considered as the best descriptor for meiofauna abundance and biomass over enzymatically hydrolysable amino acids or protein contents (Gremare et al. 2002). LPD:CHO ratio in Rufiji mangrove sediments ranged from 0.90 to 7.86 . The high LPD:CHO ratio, which is an index of energy character, support the fact that mangroves are generally considered as promoters of estuarine production. The estimated LPD:CHO ratio was significantly higher at station 3 compared to other stations (Table 1). The high LPD:CHO ratios observed in the Rufiji mangrove systems indicated the high quality of labile organic matter which supports benthic fauna in the delta.

Tannins and lignins form a significant fraction of refractory $\mathrm{OM}$ and its estimation provides valuable information on the input of terrestrially-derived organic detritus in marine systems (Lin et al. 2006). Tannin and lignin contents in this study displayed significant spatial variations $(\mathrm{p}=0.042)$ with a range of 817 to $1,787 \mu \mathrm{g} / \mathrm{g}$. The tannin and lignin contents recorded in the study area (Table 1) might be originating from terrestrial vascular plant debris. The abundance of phenolic compounds in mangrove systems has been reported by other researchers (Hernes and Hedges 2000, Hernandez et al. 2001, Kraus et al. 2003, Renjith et al. 2013, Akhil et al. 2013). Spatial variation of chlorophyll pigments in the surface sediments can be attributed to light 
availability and dissolved oxygen (DO) contents in the water column (Moreno and Niell 2004). Trend-wise, these pigment concentrations were very comparable with results from other estuaries (Sujatha et al. 2015). A highly significant positive correlation (Table 2) of chlorophyll pigments with a finegrained fraction (silt and clay) implied the effects of grain size on the pigment distribution in sediments (Moreno and Niell 2004). Autochthonous water column input contributes chlorophyll to sediments (Szymczak-Zyla and
Kowalewska 2007). In all stations, the estimated ratios of chl-a to phaeopigments and chl-a/(chl-a + phaeopigments) were low $(<1)$ signifying that phaeopigments, the early breakdown product of chl-a degrade more slowly. This ratio could also be used to suggest the relative rate and time frame of phytoplankton deposition in the estuarine environment. The combined use of these ratios in this study suggested rapid and recent deposition of phytoplankton in Rufiji mangrove sediments (Hagy et al. 2005).

Table 2: Correlation between sedimentary parameters in Rufiji mangrove sediments $(\mathrm{n}=14)$

\begin{tabular}{|l|l|l|l|l|l|l|l|l|l|l|l|l|l|l|}
\hline & Sand & Silt & Clay & TOC & TOM & TLP & PRT & CHO & T\&L & PBC & Chl-a & Chl-b & Chl-c & Phe \\
\hline Sand & 1 & & & & & & & & & & & & \\
\hline Silt & $\mathbf{- 0 . 8 6}$ & 1 & & & & & & & & & & & & \\
\hline Clay & $\mathbf{- 0 . 9 0}$ & -0.32 & 1 & & & & & & & & & & & \\
\hline TOC & -0.33 & -0.40 & -0.39 & 1 & & & & & & & & & & \\
\hline TOM & -0.18 & -0.46 & -0.33 & $\mathbf{0 . 9 5}$ & 1 & & & & & & & & & \\
\hline TLP & -0.43 & 0.28 & -0.47 & $\mathbf{0 . 7 0}$ & $\mathbf{0 . 9 4}$ & 1 & & & & & & & & \\
\hline PRT & -0.07 & 0.36 & 0.20 & $\mathbf{0 . 7 9}$ & $\mathbf{0 . 8 4}$ & 0.40 & 1 & & & & & & \\
\hline CHO & -0.19 & 0.16 & -0.34 & 0.17 & 0.26 & 0.35 & 0.21 & 1 & & & & & & \\
\hline T\&L & -0.41 & -0.06 & -0.25 & $\mathbf{0 . 6 9}$ & 0.14 & 0.29 & -0.09 & 0.16 & 1 & & & & & \\
\hline PBC & -0.41 & 0.20 & 0.02 & $\mathbf{0 . 7 6}$ & $\mathbf{0 . 8 0}$ & $\mathbf{0 . 8 4}$ & $\mathbf{0 . 7 0}$ & 0.25 & 0.24 & 1 & & & & \\
\hline Chl-a & -0.25 & $\mathbf{0 . 9 5}$ & $\mathbf{0 . 9 0}$ & 0.34 & 0.41 & 0.44 & 0.07 & 0.34 & 0.12 & 0.34 & 1 & & & \\
\hline Chl-b & -0.13 & $\mathbf{0 . 8 1}$ & $\mathbf{0 . 8 5}$ & 0.20 & 0.41 & 0.45 & 0.04 & 0.35 & 0.17 & 0.28 & $\mathbf{0 . 8 3}$ & 1 & & \\
\hline Chl-c & -0.40 & $\mathbf{0 . 7 5}$ & $\mathbf{0 . 7 2}$ & 0.01 & 0.38 & 0.43 & 0.07 & 0.27 & 0.23 & 0.25 & $\mathbf{0 . 6 6}$ & $\mathbf{0 . 9 5}$ & 1 & \\
\hline Phe & -0.05 & $\mathbf{0 . 9 0}$ & $\mathbf{0 . 8 8}$ & 0.33 & 0.34 & 0.37 & 0.06 & 0.24 & 0.05 & 0.40 & $\mathbf{0 . 9 4}$ & $\mathbf{0 . 7 2}$ & $\mathbf{0 . 5 2}$ & 1 \\
\hline
\end{tabular}

Stable carbon isotope signatures $\left(\delta^{13} \mathrm{C}\right)$ of the various carbon inputs are often different, and therefore can be used as powerful tracers of carbon sources in various ecosystems ( $\mathrm{Hu}$ et al. 2006). Enzymatic and diffusional fractionation processes lead to discrimination against ${ }^{13} \mathrm{C}$ during photosynthesis that varies between $\mathrm{C} 3, \mathrm{C} 4$ and Crassulacean Acid Metabolism (CAM) plants (Brugnoli and Farquhar 2000). In C3 plants (woody plants), $\mathrm{CO}_{2}$ is fixed within the Calvin cycle yielding C3 compounds as first products and an isotopic signature that varies between $-21 \%$ and -35 \%. In $\mathrm{C} 4$ plants, $\mathrm{CO}_{2}$ is first fixed in $\mathrm{C} 4$ organic acids that transport the carbon to separate tissues where sugar synthesis within the Calvin cycle takes place. The isotopic composition in $\mathrm{C} 4$ plants ranges between $-9 \%$ and $-20 \%$ (Badeck et al. 2005).

CAM plants have an intermediate isotopic signature between $\mathrm{C} 3$ and $\mathrm{C} 4$ with variation depending on the proportion of carbon fixed in the dark into $\mathrm{C} 4$ organic acids in the light via the Calvin cycle. Marine organic matter consequently typically has $\delta^{13} \mathrm{C}$ values between -20 and $-22 \%$. The $\sim 7 \%$ difference between organic matter produced by $\mathrm{C} 3$ land plants and marine algae has successfully been used to trace the sources and distribution of organic matter in coastal ocean sediments (Brugnoli and Farquhar 2000). In the present study, the observed $\delta^{13} \mathrm{C}$ values for mangrove sediments pointed towards the vascular plant input (mangroves- C3 woody plants). Comparatively more enriched value for $\delta^{13} \mathrm{C}$ was recorded at station 2 and more depleted values at stations 1 and 3. Generally, more enriched values were observed in the low organic carbon site, and more depleted values in organic-rich sediment sites. From the observed relationships, it can be assumed that due to the almost closed nature of station 3 , much of the mangrove area is rarely 
inundated because of the low tidal flushing and act as retention sites where mangrove carbon is a significant contributor to the sediment organic carbon pool.

The sediments from station 2 reflect a balance between inputs (possibly including microphytobenthos) and carbon imported from the water column during high tide. The more depleted $\delta^{13} \mathrm{C}$ values reported for the mangrove sediments indicate a major contribution of organic matter from the vascular plants. Various studies using the bulk parameter approach have shown that organic matter in the mangrove systems exhibit higher $\delta^{13} \mathrm{C}$ values of plant origin (Manju et al. 2012, Manju et al 2016).

Correlation analysis of mangrove sediments (Table 2) showed that BPC had highly significant positive relations with total organic carbon, total lipids and proteins. Total lipids showed highly significant positive correlations with total organic carbon. Proteins also showed significant positive correlations with total organic carbon and total organic matter. Significant correlations for tannins and lignins with total organic carbon were observed in mangrove systems. The relationships exhibited by the variables pointed towards the adsorption and diagenetic process controlling the distribution of the biochemical components in the Rufiji mangrove sediments.

Total carbohydrates did not correlate with any sedimentary parameters. The higher concentrations of carbohydrates in mangrove sediments pointed towards the possibility of inputs of vascular plant materials, especially mangrove litter. The absence of any significant correlations among some sedimentary parameters suggests different origins and diagenetic pathways of the respective parameters.

The biogeochemical processes taking place in the aquatic system mainly control the quality and quantity of sedimentary organic matter. A Principal Component Analysis (PCA) was employed to deduce the geochemical processes in the Rufiji mangrove system. The main aim of PCA was to reduce the number of variables that needed to be considered into a smaller number of indices, principal components, which can be more easily interpreted (Spencer 2002).

PCA analysis of Rufiji mangrove sediments revealed three components without significant differences accounting for a total of $92.84 \%$ variance (Table. 3). The first component accounted for $35.77 \%$ of the total variance and showed very high positive loadings on total organic carbon, total organic matter, carbohydrates, proteins and BPC. But this component had no significant loadings on sediment texture, one of the major redox indicator, signifying autochthonous input including the mangrove litter as the main source of organic matter in Rufiji mangrove sediments.

Table 3: Factor loadings for various biochemical components in Rufiji mangrove sediments

\begin{tabular}{|c|c|c|c|}
\hline \multirow{2}{*}{$\begin{array}{l}\text { Sedimentary } \\
\text { variable }\end{array}$} & \multicolumn{3}{|c|}{ Principal components } \\
\hline & PC 1 & PC 2 & PC 3 \\
\hline Sand & 0.224 & 0.179 & 0.937 \\
\hline Silt & -0.165 & 0.238 & -0.943 \\
\hline Clay & 0.011 & -0.948 & 0.064 \\
\hline $\begin{array}{l}\text { Total } \\
\text { carbon }\end{array}$ & 0.934 & 0.237 & 0.611 \\
\hline $\begin{array}{l}\text { Total organic } \\
\text { matter }\end{array}$ & 0.879 & 0.280 & 0.379 \\
\hline Lipids & 0.408 & 0.901 & 0.098 \\
\hline Proteins & 0.693 & 0.740 & -0.146 \\
\hline Carbohydrates & 0.664 & -0.507 & 0.246 \\
\hline $\mathrm{BPC}$ & 0.607 & 0.784 & -0.081 \\
\hline $\begin{array}{l}\text { Contribution rate } \\
(\%)\end{array}$ & 35.77 & 34.84 & 22.23 \\
\hline $\begin{array}{l}\text { Accumulated } \\
\text { contribution rate } \\
(\%)\end{array}$ & 35.77 & 70.61 & 92.84 \\
\hline
\end{tabular}

Component 2 exhibited high negative loadings on clay and positive loadings on lipids, proteins and BPC accounting for 34.84 $\%$ of the total variance. It also revealed a statistically significant negative loading on carbohydrates, pointing towards the diagenetic pathway. The low negative loading pattern of carbohydrates might be due to the preferential remineralisation of lipids and proteins, 
signifying that anaerobic diagenetic processes account for the second major biogeochemical process in these ecosystems. It is customary that carbohydrates are diagenetically weaker than proteins under anoxic conditions, but the reverse is true under oxic conditions (Badeck et al. 2005). Component 3 accounted for $22.23 \%$ of the total variance and exhibited high positive loadings on the sand and negative loadings on silt and total organic carbon. Due to the positive loadings on organic carbon and low loading on clay, it seems that the third component was attributed to geochemical processes which include siltation and sorption/ desorption rather than diagenesis.

\section{Conclusions}

Sedimentary organic matter was high in sediments of the Rufiji mangroves. The percentage ratio of the labile to the total organic matter indicated that most of the deposited organic matter was refractory in nature. The discrepancy between the high amounts of organic matter and its low nutritional value suggests that these ecosystems behave as a detrital trap and organic matter tends to accumulate. Texture analysis implied the predominance of silt and clay in the Rufiji mangrove sediments. The high lipid content and LPD/CHO ratio reflected the quality of organic matter to support benthic fauna, and is indicative of a better preservation of lipid compounds in the sedimentary environment. Lower PRT/CHO ratio suggested a detrital heterotrophic environment in the Rufiji mangrove environment. This ratio is also indicative of the low hydrodynamic conditions in Rufiji mangroves favouring the accumulation of sedimentary organic matter. From the bulk parameter approach, it could be seen that organic matter in sediments of the Rufiji mangrove systems is of higher plants origins. Biopolymeric carbon and the algal contributions to BPC provided important information on the better understanding of the trophic status of the area. Estimated TOC/N ratios implied the combined inputs of both terrestrial and autochthonous organic matter to sediments of Rufiji mangrove system. The more depleted $\delta^{13} \mathrm{C}$ value of bulk sedimentary organic matter implied terrestrial inputs of vascular plant debris, which was supported by higher concentrations of tannins and lignins. Chl-a/phaeopigment ratio and chl-a/(chla + phaeopigment) ratio, revealed rapid and recent deposition of phytoplankton detritus to sediments. Grain size and total organic carbon contents had substantial influence on the distribution of the biochemical composition of the Rufiji mangrove sediments. Principal component analysis revealed the association of variables and their distribution trends across the studied sites. A biomarker approach (molecular level characterization) is recommended to achieve more specific information on the degradation status of organic matter in the complex Rufiji ecosystem.

\section{Acknowledgements}

The following persons are kindly acknowledged for their help in this investigation: Mr. Richard Masinde and Amos Lugata for sampling and initial processing of samples, and Mr. Wang Fuqiang for valuable practical assistance in the laboratory.

\section{References}

Akhil PS, Nair MP and Sujatha CH 2013 Core sediment biogeochemistry in specific zones of Cochin Estuarine System (CES). J. Earth. Syst. Sci. 122: 1557-1570.

APHA (American Public Health Association) 2005 Standard methods for the examination of water and wastewater $\left(21^{\text {st }}\right.$ edn). Washington DC: APHA/American Water Works Association/Water Environment Federation.

Badeck FW, Tcherkez G, Nogues S, Piel C and Ghashghaie J 2005 Postphotosynthetic fractionation of stable carbon isotopes between plant organs-a widespread phenomenon. Rap. Comm. Mass Spec. 19: 1381-1391.

Barnes H and Blackstock J 1973 Estimation of lipids in marine animals and tissues: Detailed investigation of the sulphophosphovanillin method for 'total' lipids. J. Exp. Mar. Biol. 
Shilla - Assessment of the quality and quantity of organic matter in the Rufiji mangrove surface...

Ecol. 12: 103-118

Bligh EG and Dyer WJ 1959 A rapid method of total lipid extraction and purification. Can. J. Biochem. Physiol. 37: 911-917.

Bouillon S, Dahdouh-Guebas, F Rao AV Koedam N and Dehairs F 2003 Sources of organic carbon in mangrove sediments: variability and possible ecological implications. Hydrobiologia 495: 33-39.

Bouillon S, Moens T and Dehairs F 2004 Carbon sources sustaining benthic mineralization in mangrove and adjacent scagrass sediments (Gazi bay, Kenya). Biogeosciences 1: 71-78.

Brugnoli E and Farquhar GD 2000 Photosynthetic fractionation of carbon isotopes, In: Leegood RC, Sharkey TD, von Caemmerer $\mathrm{S}$ (Eds.). Photosynthesis: physiology and metabolism. Advances in Photosynthesis. Kluwer Academic Publishers, Netherlands.

Cividanes S, Incera M and Lopez J 2002 Temporal variability in the biochemical composition of sedimentary organic matter in an intertidal flat of the Galician coast (NW Spain). Oceanol. Acta 25: 1-12.

Dehairs F, Rao RG, Mohan PC, Raman AV, Marguillier S and Hellings L 2000 Tracing mangrove carbon in suspended matter and aquatic fauna of the Gautami-Godavari Delta, Bay of Bengal (India). Hydrobiologia 431: 225-241.

Dubois M, Gilles KA, Hamilton JK, Rebers PA and Smith F 1956 Colorimetric method for determination of sugars and related substances. Anal. Chem. 28: 350-356.

Fabiano M and Danovaro R 1994 Composition of organic matter in sediments facing a river estuary (Tyrrhenian Sea) Relationships with bacteria and microphytobenthic biomass. Hydrobiologia. 277: 71-84.

Fabiano M, Danovaro R and Fraschetti S 1995 Temporal trend analysis of the elemental composition of the sediment organic matter in subtidal sandy sediments of the Ligurian Sea (NW Mediterranean): A three years study. Cont. Shelf Res. 15: 1453-1469.

Fichez R 1991 Composition and fate of organic matter in submarine cave sediments: Implications for the biogeochemical cycle of organic carbon. Oceanol. Acta. 14: 369-377.

Gremare AL, Medernach F, Debovee JM, Amoroux G, Vetion AP and Albert P 2002 'Relationships between sedimentary organics and benthic meiofauna on the continental shelf and the upper slope of the Gulf of Lions (NW Mediterranean). Mar. Ecol. Prog. Ser. 234: 85-94.

Hagy JD, Boynton WR and Jasinski DA 2005 Modeling phytoplankton deposition to Chesapeake Bay sediments during winterspring: interannual variability in relation to river flow. Estuar. Coast. Shelf Sci. 62: 2540.

Hernandez ME, Mead R, Peralba MC and Jaffe R 2001 Origin and transport of n-alkane-2ones in a subtropical estuary: Potential biomarkers for sea grass derived organic matter. Org. Geochem. 32: 21-32.

Hernes PJ and Hedges JI 2000 Determination of condensed tannin monomers in environmental samples by capillary gas chromatography of acid depolymerization extracts. Anal. Chem. 72: 5115-5124.

$\mathrm{Hu}$ 1, Zhang $\mathrm{H}$ and Peng P 2006 Fatty acid composition of surface sediments in the subtropical Pearl River estuary and adjacent shelf, Southern China. Estuar. Coast. Shelf Sci. 66: 346-356.

Kraus TEC, Yu Z, Preston CM, Dahlgren RA and Zasoski RJ 2003 Linking chemical reactivity and protein precipitation to structural characteristics of foliar tannins. $J$. Chem. Ecol. 29: 703-730.

Lin YM, Liu JW, Xiang P, Lin P, Ye GF and Da Sternberg LSL 2006 Tannin dynamics of propagules and leaves of Kandelia candel and Bruguiera gymnorrhiza in the Jiulong River Estuary, Fujian, China. Biogeochem. 78: 343359.

Lorenzen CJ and Jeffrey SW 1980 Determination of chlorophyll in seawater; UNESCO Tech. Pap. Mar. Sci. 35: 1-20.

Lowry OH, Rosebrough NJ, Farr AL and Randall RJ 1951 Protein measurement with the Folin Phenol reagent. J. Biol. Chem. 193: 265-275.

Manju MJ, Renjith KR, Kumar CSR and 
Chandramohanakumar N 2012 Assessment of organic matter sources in the tropical mangrove ecosystems of Cochin, Southwest India. Environ. Forensics 13(3): 262-271.

Manju MN, Resmi1 P, Kumar CS, Gireeshkumar TR and Chandramohanakumar N 2016 Biochemical and stable carbon isotope records of mangrove derived organic matter in the sediment cores. Environ. Earth Sci. 75: 565.

Martin GD, Nisha PA, Balachandran KK, Madhu NV, Nair M, Shaiju P, Joseph T, Srinivas K and Gupta GVM 2011 Eutrophication induced changes in benthic community structure of a flow restricted tropical estuary (Cochin backwaters), India. Environ. Monit. Assess. 176: 427-438.

Mshale B, Senga M and Mwangi E 2017 Governing mangroves-unique challenges for managing Tanzania's coastal forests. USAID, 6689. USAID Reports Brief, p. 8.

Minu A, Routh J, Dario M, Bilosnic M, Kalén R, Val Klump J and Machiwa JF 2018 Temporal and spatial distribution of trace metals in the Rufiji delta mangrove, Tanzania. Environ. Monit. Assess. 190(6): 1-19.

Minu A, Joyanto R and Machiwa JF 2020 Distribution and sources of organic matter in the Rufiji Delta in Tanzania: Variability and environmental implications. Appl. Geochem. 122: 104733 .

Moreno S and Niell FX 2004 Scales of variability in the sediment chlorophyll content of the shallow Palmones River Estuary, Spain. Estuar. Coast. Shelf Sci. 60: 49-57.

Nair SM, Balchand AN and Nambisan PNK 1989 On the determination and distribution hydroxylated aromatic compounds in estuarine waters. Toxicol. Environ. Chem. 22: 203-213.

Pusceddu A, Dell'Anno A, Fabiano $M$ and Danovaro R 2004 Quantity and biochemical composition of organic matter in marine sediments. Biol. Mar. Mediterr. 11: 39-53.

REMP 2003 A summary Report on biodiversity of Rufiji District-Rufiji Environmental Management Project Technical Report No. 44.

Renjith KR, Manju MJ, Prosenjit GK, Habeeb R, Ratheesh KCS and Chandramohanakumar N
2013 Biogeochemical facsimile of the organic matter quality and trophic status of a microtidal tropical estuary. Environ. Earth Sci. 70: 729-742.

Salas PM, Sujatha CH and Ratheesh-Kumar CS 2015 Fate and source distribution of organic constituents in a river dominated tropical estuary. J. Earth Syst. Sci. 124: 1265-1279.

Shilla DJ and Routh J 2017 Using biochemical and isotopic tracers to characterize organic matter sources and their incorporation into estuarine food webs (Rufiji Delta, Tanzania). Chem. Ecol. 33: 893-917.

Shilla DA 2019 Sources and major biogeochemical pathways of organic matter in the mangrove system of Rufiji estuary. Chem. Ecol. 35(6): 524-536.

Shilla DJ and Shilla DA 2020 Assessment of the geochemical characteristics of water and surface sediment of Rufiji Mangrove Forest, Tanzania. Tanz. J. Sci. 46(2): 482-497.

Sørensen C 1998 Fisher, farmer, forester: smallholder management in the Rufiji Delta of Tanzania. A field report presented to the Danish Council for Development Research, $96 \mathrm{pp}$.

Spencer 2002 Spatial variability of heavy metals in the intertidal sediments of the Medaway Estuary, Kent, UK. Mar. Poll. Bull. 44: 933944.

Sujatha MT, Jayachandra PL and Anandakumar VSD 2015 Percentage incidence, morphology and morphometry of myocardial bridges: a cadaveric study. Int. J. Anat. Res. 3(2): 10921098.

Szymczak-Zyla M and Kowalewska G 2007 Chloropigmentsa in the Gulf of Gda'nsk (Baltic Sea) as markers of the state of this environment. Mar. Poll. Bull. 55: 512-528.

Tolosa I, Vescovali I, LeBlond N, Marty JC, De Mora S and Prieur L 2004 Distribution of pigments and fatty acid biomarkers in particulate matter from the frontal structure of the Alboran Sea (SW Mediterranean Sea). Mar. Chem. 88: 103-125. 